\title{
Population traits of the burrowing toad Rhinella fernandezae (Gallardo, 1957) (Anura, Bufonidae)
}

\author{
Sanchez, $L C$. ${ }^{\mathrm{a} *}$ and Busch $M$. $^{\mathrm{b}, \mathrm{c}}$ \\ ${ }^{a}$ Centro de Investigación Científica y Transferencia de Tecnología a la Producción - CICyTTP-CONICET, \\ Matteri and España, 3105, Diamante, Entre Ríos, Argentina \\ bLaboratorio de Ecología de Roedores, Departamento de Ecología, Genética y Evolución, Facultad de Ciencias Exactas y \\ Naturales de la UBA, Ciudad Universitaria, Pabellón 2, Cuarto piso, C1428EHA, Buenos Aires, Argentina \\ ${ }^{c}$ Consejo Nacional de Investigaciones Científicas y Tecnológicas - CONICET \\ *e-mail: lauracecilias@gmail.com
}

Received November 17, 2005 - Accepted February 5, 2007 - Distributed February 29, 2008

(With 2 figures)

\begin{abstract}
Size distribution, sex ratio and use of burrows of the burrowing toad Rhinella fernandezae were studied in Buenos Aires province, Argentina. Two sites separated by approximately $300 \mathrm{~m}$ were studied: one was a road next to a swamp, and the other a garden of a country house located further from the swamp. We identified toad burrows, and individuals were sexed, measured and given an individual mark. Burrows were examined in subsequent months after the first sampling to assess the presence of toads. We found significant differences in the size distribution between areas, being the proportion of juveniles greater at the site next to the swamp where the reproduction of the species was observed. This result may suggest that the site located near to the swamp functions as a source habitat of individuals that migrate to the other site, where recruitment would be very scarce. Sex proportion of adults did not differ from 1:1 in neither the total population nor in each site, suggesting that there was not differential mortality by sex. Some toads changed burrows throughout the study period, but there were not differences in the frequency of change between adults and juveniles.
\end{abstract}

Keywords: size distribution, sex ratio, burrows use, Rhinella fernandezae, Argentina.

\section{Características populacionais do sapo Rhinella fernandezae (Anura, Bufonidae)}

\begin{abstract}
Resumo
Distribuição de tamanho, razão sexual operacional, e uso de covas do sapo Rhinella fernandezae foram estudados na província de Buenos Aires, Argentina, em dois sítios afastados $300 \mathrm{~m}$. Um deles é uma trilha próxima a um pântano, o outro, um jardim de uma casa rural, mais afastado do pântano. Identificamos as covas dos sapos, e os indivíduos dentro delas foram sexados, medidos e marcados individualmente. As covas foram monitoradas mensalmente, depois da primeira amostragem para avaliar a presença dos sapos. Achamos diferenças na distribuição de tamanhos entres os sítios, sendo a proporção de juvenis maior naquele próximo ao pântano, onde a reprodução da espécie foi observada. O resultado sugere que o sítio próximo ao pântano funciona como um habitat fonte de indivíduos que migram para aquele mais afastado, onde o recrutamento seria escasso. A taxa entre os sexos dos adultos não foi diferente de 1:1 em nenhum dos sítios amostrados, nem na população total, sugerindo que não existe mortalidade diferencial entre machos e fêmeas. Alguns sapos mudaram de cova durante o período do estudo, mas não houve diferenças na frequiência de mudança entre juvenis e adultos.
\end{abstract}

Palavras-chave: distribuição de tamanho, razão sexual operacional, uso de covas, Rhinella fernandezae, Argentina.

\section{Introduction}

Rhinellafernandezae is a toad found in Uruguay, southern Paraguay, southern Brazil and northeastern Argentina (IUCN et al., 2004). This species reproduces from October to March (Gallardo, 1957) in ponds, ditches, flooded areas, temporary swamps, and occasionally the periphery of permanent lakes. $R$. fernandezae live in individual burrows dug with their legs in the moist soil where both males and females spend most of the day (Gallardo, 1957), foraging invertebrates that pass near the burrow (Lajmanovich, 1995). They leave their burrows for breeding, returning thereafter (Gallardo, 1957). They can also live in burrows left by other individuals (Gallardo, 1957; 1969). 
There are few works on population ecology of $R$. fernandezae, and they generally focus on its reproductive biology (Fernández, 1927; Martori et al., 2004). Although little is known on the activity of $R$. fernandezae, Gallardo (1957) observed that toads can orient themselves and return to their burrows (homing). It was observed that individuals that had just metamorphosed, built burrows close to the swamp where they lived as larvae, gradually moved away, and built new burrows as they become larger (Gallardo, 1969). Therefore, we expect that the population structure of this species in areas near the water where they breed would differ from those in other areas. Such difference would be mainly expressed in a greater frequency of juveniles in sites near water ponds. On the other hand, if burrow changes are related to changes in body size (Gallardo, 1969), it would be expected that juveniles would change burrows more frequently than the whole population.

The aim of this work was to study population traits of $R$. fernandezae as size distribution, sex ratio and the use of burrows.

\section{Materials and Methods}

\subsection{Study area}

The study was conducted at Escobar (34 $21^{\circ} \mathrm{S}$ and $58^{\circ} 48^{\prime} \mathrm{W}$ ), Buenos Aires province, Argentina. We studied the toad population at two sites located about $300 \mathrm{~m}$ apart. Site 1 was an unpaved road (approximately four meters wide and $600 \mathrm{~m}$ long) which is connected to the Luján River. This site was located next to a large swamp where $R$. fernandezae was observed reproducing. The side of the road was covered by natural vegetation (e.g. grasses, sedges, broad-leafed plants, shrubs and trees), and the soil was saline. Site 2 was a garden of a country house located in a ravine between the low area near the river and the highland. This site was approximately $300 \mathrm{~m}$ from the swamp. The $3000 \mathrm{~m}^{2}$ garden was covered by cultivated trees and grass that was kept short.

\subsection{Sampling design}

Between October and November 2002 we conducted a preliminary sampling in which we looked for burrow toads at both sites. We identified 32 burrows in Site 1 and 34 burrows in Site 2. In all cases, the presence of a toad in the burrow was verified. We labeled these burrows and marked individually the toads by toe clipping. We avoided cutting the first and second finger because of their importance in the amplexus. In order to assess the changes of burrows we returned to the sites in December of the same year (count 1), January (count 2) and March 2003 (count 3).

\subsection{Size distribution and sex proportion}

All toads identified between October and November 2002 were measured (snout-vent lengths, SVL) to the nearest $0.02 \mathrm{~mm}$ using a Vernier caliper. Individuals with an SVL smaller than or equal to $42 \mathrm{~mm}$ and lacking secondary sex characteristics were considered juveniles (both males and females, class 1), adult males were identified according to a length greater than $42 \mathrm{~mm}$ and with external vocal sac dark-colored and dark thumb pads in the first and second fingers. We used $42 \mathrm{~mm}$ as the size that discriminates between adults and juveniles because we did not capture any toad with secondary sexual characteristics smaller or equal to this size. Adults were classified in two categories: class $2=42<\mathrm{SVL} \leq 54 \mathrm{~mm}$ and class $3=\mathrm{SVL}>54 \mathrm{~mm}$. Individuals were then reintroduced in their respective burrows. Size distribution of toads was compared between sites by means of a contingency table (Zar, 1996). When statistically significant differences were found, we identified the category that differs by using an analysis of subdividing contingency tables (Zar, 1996).

Whether the relation of males to females differed from 1:1 was assessed by means of a $\mathrm{G}$ test, both for the whole population and for each site. Sex proportions were compared between sites by means of the test of difference between proportions (Sokal and Rohlf, 1999).

\subsection{Use of burrows}

In order to study the use of burrows, we monitored 32 burrows in Site 1 and 34 burrows in Site 2. The initially labeled burrows were re-identified in each count and when the toad was present, it was withdrawn and its identity was verified. New toads that appeared in the labeled burrows were also individualized by toe clipping, measured, and they then became part of the stock of monitored toads. When a toad was not found in its burrow, we looked around within the surroundings. If the individual was found in a new burrow, it was labeled.

The proportion of burrow changes was estimated from the monitoring of recaptured individuals between samplings. The proportion of individuals that changed burrows (C proportion) was calculated as: number of recaptured toads that changed burrow / number of recaptured toads.

The $\mathrm{C}$ proportions were compared between Site 1 and Site 2 using tests of difference between proportions (Sokal and Rohlf, 1999). The p-level was computed based on the t-value for the respective comparison:

$|t|=[(N 1 * N 2) /(N 1+N 2)]^{1 / 2 *}|p 1-p 2| /(p * q)^{1 / 2}$

where:

$\mathrm{p}=(\mathrm{p} 1 * \mathrm{~N} 1+\mathrm{p} 2 * \mathrm{~N} 2) /(\mathrm{N} 1+\mathrm{N} 2)$ and $\mathrm{q}=(1-\mathrm{p})$

Whether some of the defined categories (juvenile, adult male, adult female) had a greater tendency to change burrows was analyzed by employing the binomial likelihood function (Sokal and Rohlf, 1999):

$P(x)=[n ! / x !(n-x) !] p^{x} \cdot q^{(n-x)}$

where $n$ represents the total number of recaptured individuals (juveniles, females or males), $\mathrm{x}$ the recaptured juveniles, females or males that had changed burrows, 
$\mathrm{p}$ the likelihood of burrow change calculated according to the $\mathrm{C}$ proportion for all counts and for the whole population, and $\mathrm{p}(\mathrm{x})$ the likelihood that $\mathrm{x}$ juveniles, $\mathrm{x}$ females or $\mathrm{x}$ males changed burrows according to the burrow changes proportion observed in the general population.

In each study area we evaluated (according to Begon, 1979) whether the initial marking decreased the chances of being recaptured. Of the $r_{i}$ individuals released on day $i$, some will have been caught (and marked) on days prior to day $i$, and some will not. If the chances of dying are increased by the initial marking, then the individuals who were marked for the first time on day $i$ will be under-represented in subsequent samples. So, a contingency table was made and observed and expected frequencies were compared by an $\mathrm{X}^{2}$ test.

The STATISTICA program, 6.0 version (Statsoft, 2001) was used for the statistical procedures.

\section{Results}

\subsection{Size distribution and sex proportion}

The size of toads marked ranged from 32.40 to $65.30 \mathrm{~mm}$. Considering the three counts, the SVL distribution was: $25.76 \%$ of class 1 juveniles, $43.94 \%$ of class 2 individuals and $30.30 \%$ of class 3 . Among adults, $46.94 \%$ were males and $53.06 \%$ were females. The sex proportion did not differ from 1:1 $(\mathrm{Gw}=0.182 ; 0.1<\mathrm{p}<0.95)$.

The size distribution differed significantly between sites (Figure 1; Gw $=8.30 ; 0.01<\mathrm{p}<0.025$ ), because of a greater proportion of juveniles in Site 1 (Contingency table without juveniles: $\mathrm{Gw}=1.08$ and $0.1<\mathrm{p}<0.95$; and Contingency table of juveniles vs. no juveniles: $\mathrm{Gw}=7.22$ and $0.005<\mathrm{p}<0.01$ ). The male to female relation did not differ from 1:1 in either study site (Site 1 $\mathrm{Gw}=0.049 ; 0.1<\mathrm{p}<0.95$, and Site $2 \mathrm{Gw}=0.131,0.1<$ $\mathrm{p}<0.95$ ). In addition, the proportion of males did not present differences between sites (Statistic of proportion test $=0.05, \mathrm{p}=0.962$ ).

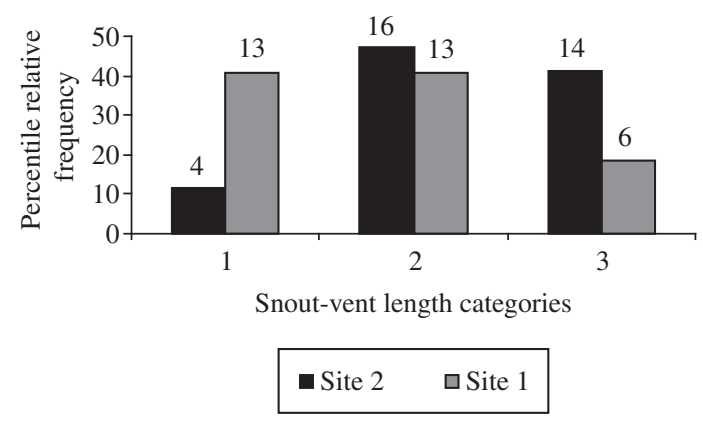

Figure 1. Percentiles relative frequencies for the snout-vent length categories: class $1=\leq 42 \mathrm{~mm}$; class $2=>42 \mathrm{~mm}$ - $\leq 54 \mathrm{~mm}$; class $3=>54 \mathrm{~mm}$. The $\mathrm{p}$ value is: $0.01<\mathrm{p}$ $<0.025$. The number over the bars indicates the number of individuals measured in each case.

\subsection{Use of burrows}

We marked a total of 46 toads in Site 1 and 44 in Site 2 in 74 burrows ( 36 total burrows in the first and 38 in the second). A total of 12 indiviudals (eight in Site 1 and four in Site 2) remained all the study period in the burrow where they had been originally found.

We did not find differences in the frequency of burrow changes according to the size or sex in both studied sites (Table 1).

The $\mathrm{C}$ proportion varied between $7.69 \%$ and $17.65 \%$ in Site 1 and between $5.88 \%$ and $33.33 \%$ in Site 2 (Figure 2). There were not significant differences in this proportion between sites $\left(1^{\text {st }}\right.$ count $p=0.584,2^{\text {nd }}$ count $\mathrm{p}=0.683$, and $3^{\text {rd }}$ count $\left.\mathrm{p}=0.141\right)$.

Initial marking did not have a significant effect on the probability of subsequent recaptures (Site 1: $1^{\text {st }}$ count $p=1.000$, and $2^{\text {nd }}$ count $p=0.544$; Site $2: 1^{\text {st }}$ count $\mathrm{p}=1.000$, and $2^{\text {nd }}$ count $\left.\mathrm{p}=0.529\right)$.

\section{Discussion}

The size distribution of the whole population showed a low percentage of juveniles, and the lower size found

Table 1. Likelihood that $\mathrm{x}$ juveniles, $\mathrm{x}$ females or $\mathrm{x}$ males changed burrows $(\mathrm{p}(\mathrm{x}))$ at Site 1 and Site 2, according to the proportion of burrow changes observed in the general population ( 0.344 in the road and 0.261 in the country house). $n$ represents the total number of recaptured juveniles, females or males.

\begin{tabular}{clrrr}
\hline Site & Category & $\mathbf{x}$ & $\mathbf{n}$ & $\mathbf{P}(\mathbf{x})$ \\
\hline Site 2 & juveniles & 2 & 2 & 0.068 \\
Site 2 & females & 1 & 9 & 0.209 \\
Site 2 & males & 3 & 12 & 0.257 \\
Site 1 & juveniles & 3 & 10 & 0.255 \\
Site 1 & females & 5 & 13 & 0.213 \\
Site 1 & males & 3 & 9 & 0.273 \\
\hline
\end{tabular}

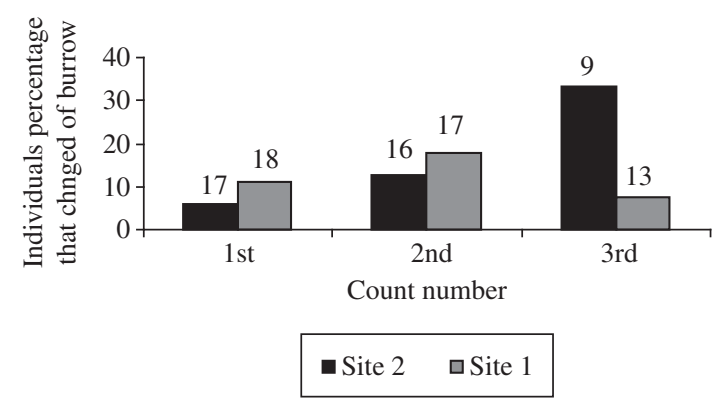

Figure 2. Percentage of individuals that changed burrows in the three counts at Site 2 and at Site 1 (C proportion $x$ 100). The numbers over the bars indicate the number of recaptured individuals in each case. 
corresponded to toads that were probably recruited in the previous reproductive season. This result may be the consequence of a delay in the beginning of the current reproductive season, because we did not observe reproduction since late December, after a rainy period. We can not discard, however, that our sampling procedure may have underestimated the number of juveniles.

The greater proportion of juveniles in Site 1 with respect to Site 2 is according to our first hypothesis, that toads show movements from areas near the reproducing sites to more distant places (Gallardo, 1969), and this juvenile dispersal may reduce local competition (Zug et al., 2001). Adult toads at Site 2 may have migrated from other places where reproduction took place, such as at Site 1. These differences in the size distribution between sites can be interpreted according to the theory of source-sink dynamics (Pulliam, 1988), in which Site 1 would be the source habitat (where recruitment exceeds mortality), and Site 2 the sink habitat.

The adult sex proportion of 1:1 suggests that there is no differential mortality between sexes. This is consistent with that observed by Yanosky et al. (1997) for a population of $R$. fernandezae of the El Bagual Ecological Reserve, Northeastern Argentina, and with that observed by Blair (1943) in populations of Anaxyrus americanus (Holbrook, 1836) in Oklahoma.

Rhinella fernandezae individuals seem to maintain their burrows during long periods, since the proportion of individuals that remained in their burrows was greater than the proportion of individuals that changed burrows. However, if we considered that toads which were not recaptured could have changed burrows, the proportion of individuals that changed burrows would be higher. Then, burrow changes may have been underestimated.

Results did not support our hypothesis that juveniles would change burrows more frequently than adults, and there were not differences between sites in the frequency of burrow change, as would have been expected from their differences in size distribution.

The two sites did not show differences in most of the evaluated population traits, except in the size distribution. We consider that both sites belong to the same population, but individuals are differentially distributed in the space according to their life stage. However, we do not have evidence of their movements because we did not recapture marked individuals of Site 1 in Site 2. More detailed studies and long-term monitoring may help to understand the causes of these results.

Acknowledgments - We greatly acknowledge the help in the early stages of this work from our colleagues at the laboratory of rodent ecology (FCEN, UBA). G Carrizo and J. Faivovich provided valuable literature. A. Ambas, B. Blotto, C. Díminich and P. Bellini helped us in the field. We are also grateful to the house keeper and owners of the country house for allowing us to sample in their property. We thank P. Peltzer and R. Lajmanovich for their valuable comments on this manuscript. This work was partially supported by PICT 11928 .

\section{References}

BEGON, M., 1979. Investigating animal abundance: capturerecapture for biologists. Edward Arnold, London, 97 p.

BLAIR, AP., 1943. Population structure in toads. Am. Nat., vol. 77 , no. 733 , p. $563-568$.

FERNÁNDEZ, K., 1927. Sobre la biología y reproducción de batracios argentinos (segunda parte). Bol. Acad. Nac. Cienc. Córdoba, vol. 29, p. 271-320

GALLARDO, JM., 1957. Las subespecies argentinas de Bufo granulosus Spix. Rev. Mus. Arg. Cienc. Nat. "B. Rivadavia" Zool. vol. 3, no. 6, p. 336-374.

-, 1969. La distribución de las subespecies de Bufo granulosus Spix: su fidelidad a los sistemas hidrográficos sudamericanos. Cienc. Invest., vol. 25, no. 9, p. 406-416.

IUCN, CONSERVATION INTERNATIONAL, and NATURE SERVE, 2004. Global Amphibian Assessment. www. globalamphibians.org. (Accessed on 15 October 2004).

LAJMANOVICH, RC., 1995. Relaciones tróficas de bufónidos (Anura: Bufonidae) en ambientes del río Paraná, Argentina. Alytes, vol. 13, no. 3, p. 87-103.

MARTORI, R., AUN, L., BIRRI A., ROZZI GIMÉNEZ, C. and HEREDIA, E., 2004. Reproducción comparada de tres especies de anuros sintónicos de una localidad del sudoeste de Córdoba. Cuad.Herpetol., vol. 18, no. 2, p. 43-59.

PULLIAM, HR., 1988. Sources, Sinks, and population regulation. Am. Nat., vol. 132, no. 5, p. 652-661.

SOKAL, RR. and ROHLF, FJ., 1999. Introducción a la Bioestadística. Editorial Reverté, Barcelona, 362 p.

STATSOFT, 2001. Statistica for Windows, Release 6.0. Computer program manual. Statsoft, Inc. Tulsa, OK, USA.

YANOSKY, AA., MERCOLLI, C. and DIXON, JR., 1997. Field ecology of the pygmy toad Bufo pygmeus (Anura: Bufonidae), in northeastern Argentina with notes on sympatric sibling species of the granulosus Group. Bull. Maryland Herpetol. Soc., vol. 33, no. 2, p. 66-77.

ZAR, JH., 1996. Biostatistical Analysis. 3. ed., Prentice Hall, New Jersey, 918 p.

ZUG, GR., VITT, LJ. and CALDWELL, JP., 2001. Herpetology. An introductory biology of amphibians and reptiles. 2. ed., Academic Press, San Diego, 538 p. 